Arq. Bras. Med. Vet. Zootec., v.71, n.1, p.303-313, 2019

\title{
The polymorphisms of genes associated with the profile of fatty acids of sheep
}

\author{
[Os polimorfismos de genes associados ao perfil de ácidos graxos de ovinos] \\ C. Esteves ${ }^{1}$, K.G. Livramento ${ }^{1}$, L.V. Paiva ${ }^{1}$, A.P. Peconick ${ }^{1}$, I.F.F. Garcia ${ }^{1}$, \\ C.A.P. Garbossa ${ }^{2}$, P.B. Faria ${ }^{1}$ \\ ${ }^{1}$ Universidade Federal de Lavras - Lavras, MG \\ ${ }^{2}$ Universidade Federal Rural da Amazônia - Belém, PA
}

\begin{abstract}
The present study aimed to evaluate the occurrence of polymorphisms in Diacylglycerol acyltransferase (DGTA-1 and 2), Fatty acid synthase $(F A S N)$, Stearoyl-CoA desaturase $(S C D)$ genes and the Thioesterase domain of $F A S N$ (TE-FASN) gene that may be related to the lipid profile. In the experiment, a total of 84 sheep from different genetic groups were used. For the evaluation of the polymorphism of the genes, PCR-Single Strand Conformation Polymorphism (SSCP) technique and subsequent sequencing were used. In DGAT-2 gene, four genotypes were identified with the presence of 6 polymorphisms, with two (c.229T> C; c.255T> C) that resulted into the exchange of phenylalanine by leucine. In FASN gene, two genotypes were identified. In TE-FASN gene, three genotypes and 17 polymorphisms were identified. $D G A T-1$ and $S C D$ genes did not reveal the occurrence of polymorphism. There was difference in relation to C14: 0, C18: 0 fatty acids and $\triangle 9$-desaturase ${ }^{\mathrm{C} 18}$ for DGAT-2 gene and of C18: $2 \omega 6 \mathrm{t}$ for TE-FASN.

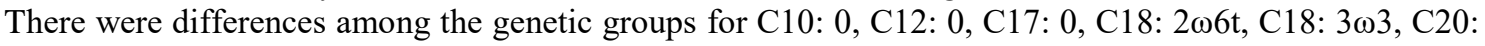
2 , total of $\omega 3, \omega 3 / \omega 6$ and atherogenicity index. There is occurrence of polymorphism of DGAT-2 and TEFASN genes and these should be further studied in sheep since they revealed influence of the genotypes on the fatty acid profile.
\end{abstract}

Keywords: diacylglycerol acyltransferase, fatty acid synthase, stearoyl-CoA desaturase

\section{RESUMO}

O presente estudo teve o objetivo de avaliar a ocorrência de polimorfismos nos genes Diacilglicerol aciltransferase (DGTA1 e 2), Ácido graxo sintase (FASN), Estearoil-CoA dessaturase (SCD) e o Domínio da tioesterase do gene FASN (TE-FASN), que possam estar relacionados ao perfil lipídico. No experimento, foram utilizados um total de 84 ovinos de diferentes grupos genéticos. Para avaliação do polimorfismo dos genes, foi utilizada a técnica de polimorfismo de conformação de cadeia simples (PCRSSCP) e posterior sequenciamento. No gene DGAT-2, foram identificados quatro genótipos com a presença de seis polimorfismos, com dois $(c .229 T>C ;$; c.255T>C) que resultaram na troca da fenilalanina por leucina. No gene FASN, foram identificados dois genótipos. No gene TE-FASN, foram identificados três genótipos e 17 polimorfismos. Os genes DGAT-1 e SCD não revelaram a ocorrência de polimorfismo. Houve diferença em relação aos ácidos graxos C14:0, C18:0 e $\Delta 9$-desaturase ${ }^{\text {Cl8 }}$ para o

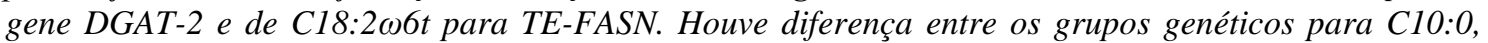
C12:0, C17:0, C18:2 $\omega 6 t, C 18: 3 \omega 3, C 20: 2$, total de $\omega 3, \omega 3 / \omega 6$ e índice de aterogenicidade. Há ocorrência de polimorfismo dos genes DGAT-2 e TE-FASN, e estes devem ser mais estudados em ovinos, pois revelaram influência dos genótipos sobre o perfil de ácidos graxos.

Palavras-chave: diacilglicerol aciltransferase, ácido graxo sintase, estearoil-CoA dessaturase

Recebido em 12 de agosto de 2016

Aceito em 3 de fevereiro de 2017

E-mail: claudianaesteves@yahoo.com.br 


\section{INTRODUCTION}

At present, much attention has been paid to the composition of fatty acids in meats, due to their influence on quality, since intramuscular fat is responsible for the tenderness and juiciness of cooked meat (Wood et al., 2003) and human health. The lipid composition, in saturated fatty acids (AGS), affects adipose tissue firmness and oxidative stability of muscles, influencing meat processing (Wood et al., 2008). It is known that some AGS, commonly found in meat and dairy products, especially myristic and palmitic acids, raise total cholesterol and the low-density lipoprotein levels and are therefore risk factors for heart disease (Erkkilä et al., 2008). Although, the effects of fatty acids on health are well studied and known, the molecular mechanisms that control their synthesis in different species are not yet fully understood.

The process of AG synthesis in meat involves some enzymes, such as Fatty Acid Synthase FASN (Chu et al., 2015; Zhang et al., 2008), Diacylglycerol Acyltransferase - DGAT (Bouwman et al., 2012; Zhang et al., 2014) and Stearoyl-CoA desaturase - SCD (HenriquezRodriguez et al., 2015; Barton et al., 2010). Stearoyl-CoA desaturase enzyme $(S C D)$ is required in the biosynthesis of monounsaturated

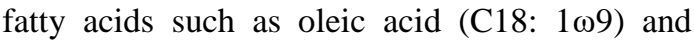
palmitoleic (C16: 1 $\omega 9)$, which are produced after insertion of unsaturation in the $\Delta 9$ position of their precursors, C18: 0 and C16: 0 fatty acids (Guillou et al., 2010). While, Diacylglycerol acyltransferase enzymes (DGAT-1 and DGAT-2) catalyze the final step of triacylglycerol (TAG) formation (Cases et al., 1998). DGAT-1 acts by incorporating an oleoyl-CoA in TAG and DGAT2 is responsible for the accumulation of lipids (McFie et al., 2011).

Thus, many works aimed to understand the activity of these enzymes with the purpose of associating the lipid profile of meat with single nucleotide polymorphisms (SNPs) present in their genes. Some results indicate that the presence of SNPs in FASN, SCD and FABP4 genes (Fatty acid binding protein 4) may influence the composition of fatty acids in ruminants (Maharani et al., 2012). In cattle, 5 SNPs were observed in FASN gene, identified along different breeding studies and one of them was associated with lipid composition, and can be used as a marker in breeding programs (Bhuiyan et al., 2009). In the same way, in goats, a SNP in the exon 3 of DGAT-2 gene was found, being characterized as a possible molecular marker (Fang et al., 2012). However, studies in sheep are still scarce for these genes.

The present study intended to analyze the occurrence of SNPs of DGAT-1 and 2, FASN, $S C D$ genes and Thioesterase domain of FASN gene in different genetic groups of sheep and check its association with lipid composition.

\section{MATERIAL AND METHODS}

The experiment used a total of 84 lambs, 14 purebred Santa Inês (SI) animals, 16 1/2 SI x 1/2 Black Dorper (BD) animals; 12 animals $1 / 2$ SI x $1 / 2$ White Dorper (WD); 19 animals $1 / 2$ SI x $1 / 2$ Texel (TX); 14 animals $1 / 2$ SI x $1 / 2$ Lacaune (LC); 19 animals 1/2 SIx 1/2 East Friesan animals (EF) from SI dams and six different sires, in a randomized block design. The lambs were fed ration containing $80 \%$ concentrate and $20 \%$ roughage, based on oat hay, coffee husk, soybean meal, corn, limestone, mineral supplement and Rumensin ( ${ }^{\circledR}$ and bypass fat (Megalac) at 5, 3\% of the ration until the moment of slaughter. The sheep were slaughtered through a humanitarian method and use of good hygiene practices with a live weight of $43.99 \pm 1.21 \mathrm{~kg}$ (CEUA UFLA Protocol Number. 102/12).

Prior to slaughter, to conduct DNA evaluations approximately $5 \mathrm{ml}$ of blood was collected in a tube containing EDTA potassium $[50 \mu \mathrm{L} 15 \%$ EDTA (K3)]. The samples were identified and stored at $-80^{\circ} \mathrm{C}$ and the genomic DNA was extracted according to the protocol of Regitano (2001). The PCR was performed from 50ng of genomic DNA in a final volume of $25 \mu \mathrm{l}$ containing $1 \times$ reaction buffer, $200 \mu \mathrm{M}$ of dNTP, $1.25 \mathrm{U}$ of Taq DNA polymerase, $2.5 \mathrm{mM}$ of $\mathrm{MgCl}$ and $0.5 \mu \mathrm{M}$ of each primer and $\mathrm{H}_{2} \mathrm{O}$. The PCR products obtained for the different primers (Table 1) were subjected to $1.0 \%$ agarose gel electrophoresis. Amplification was performed in the thermocycler (MasterCycler - Eppendorf, USA). 
The polymorphisms...

Table 1. Sequence of the primers and conditions established of annealing temperature of PCR for the amplification of the fragments of DGAT-1, DGAT-2, FASN, SCD and TE-FASN genes

\begin{tabular}{|c|c|c|c|c|}
\hline Gene & $\mathrm{pb}$ & Sequence of primers $\left(5^{\prime}-3^{\prime}\right)$ & Annealing & Reference \\
\hline DGAT 1 & 381 & $\begin{array}{l}\text { CCATCCTCTTCCTCAAGCTG } \\
\text { GGGAAGTTGAGCTCGTAGCA }\end{array}$ & $59^{\circ} \mathrm{C}$ for $30^{\prime}$ & Conte et al. (2010) \\
\hline DGAT 2 & 268 & $\begin{array}{l}\text { CGAGCCCATTACCATCCC } \\
\text { AAATAACCCACAGACACCC }\end{array}$ & $61^{\circ} \mathrm{C}$ for $30^{\prime \prime}$ & Fang et al. (2012) \\
\hline FASN & 228 & $\begin{array}{l}\text { GACCTTGACACGGCTCAACT } \\
\text { GGGCACAGCATGAGGTTTAG }\end{array}$ & $60^{\circ} \mathrm{C}$ for $30^{\prime \prime}$ & $\begin{array}{l}\text { Ciecierska et al. } \\
\text { (2013) }\end{array}$ \\
\hline SCD & 377 & $\begin{array}{l}\text { TGAGGGCTTCCACAACTA } \\
\text { GCATCATAAAGGCAGAGT }\end{array}$ & $57^{\circ} \mathrm{C}$ for $30^{\prime \prime}$ & Zhang et al. (2010) \\
\hline TE-FASN & 505 & $\begin{array}{c}\text { AGAGCCTGGCCACCTACTACATC } \\
\text { TGCCACACGCGCCTCCAGA }\end{array}$ & $56^{\circ} \mathrm{C}$ for $30^{\prime}$ & Oztabak et al. (2014) \\
\hline
\end{tabular}

About $1 \mu$ l of each PCR product was diluted in $10 \mu \mathrm{l}$ of denaturing buffer $(98 \%$ formamide, $20 \mathrm{mM}$ EDTA, $0.05 \%$ bromophenol blue and $0.05 \%$ xylene cyanol), denatured at $95^{\circ} \mathrm{C}$ for $5 \mathrm{~min}$ and maintained on ice. The total volume was applied onto $12.5 \%$ polyacrylamide gel. Electrophoresis was performed at $10^{\circ} \mathrm{C}$ in $0.5 \times$ TBE buffer (100mM Tris, $9 \mathrm{mM}$ boric acid, $1 \mathrm{mM}$ EDTA) for approximately $6 \mathrm{~h}$ at $300 \mathrm{~V}$. Thereafter, the polyacrylamide gels were stained with silver according to Byun et al. (2009).

Sequencing reactions were performed by capillary electrophoresis on ABI3130 apparatus using POP7 polymer and BigDye Terminator V3.1 Cycle Sequencing Kit (Applied Biosystems, Madrid, Spain). The generated spherograms and nucleotide sequences were analyzed by the free software Sequence Scanner Software (Applied Biosystems ${ }^{\circledR}$ ) and JustBio's computational tools (www.justbio.com), respectively. Homologous searches and sequence alignment were performed with BLAST (https://blast.ncbi.nlm.nih.gov/Blast.cgi) and with ClustalW2 program (http://www.ebi.ac.uk/ Tools/msa/ Clustalw2 /).

For the conduction of the analyses of the fatty acid profile, samples of cover fat of the longissimus lumborum muscle of each animal were collected. The extraction of the lipids followed the methodology of Folch et al. (1957) and fatty acids were esterified according to Hartman and Lago (1973). Fatty acid analysis was carried out by gas chromatography on a Shimatzu CG 2010 chromatograph (Agilent Technologies Inc., Palo Alto, CA, USA), equipped with flame ionization detector, split injector at the 1:50 ratio and capillary column of Supelco SPTM-2560, $100 \mathrm{~m} \quad \mathrm{X} \quad 0.25 \mathrm{~mm} \quad \mathrm{X}$
$0.20 \mu \mathrm{m}$ (Supelco Inc., Bellefonte, PA, USA). The chromatographic conditions were initial column temperature of $140^{\circ} \mathrm{C} / 5 \mathrm{~min}$; increased $4^{\circ} \mathrm{C} / \mathrm{min}$. up to $240^{\circ} \mathrm{C}$ and maintained for $30 \mathrm{~min}$., totaling 60 minutes. The temperature of the injector and detector was $260^{\circ} \mathrm{C}$.

The carrier gas used was helium. The fatty acids were identified by comparison to the retention times presented by the chromatographic standard SupelcoTM37 FAME Standard Mix (Supelco Inc., Bellefonte, PA, USA) and expressed in percentage $(\%)$ of the total of fatty acids identified and then grouped into: total saturated, monounsaturated and polyunsaturated fatty acids. The activity of $\Delta 9$ desaturase C16, C18, elongase and Thioesterase enzymes was estimated according to Malau-Aduli et al. (1997) and Kazala et al. (1999). The atherogenicity and thrombogenicity indices were obtained according to Ulbricht and Southgate (1991).

Genotypic frequency and allele frequency were performed by direct counting. In the statistical analysis, the SAS statistical package ((Statistical Analysis System, 2011) was used to determine the normality of the data (Shapiro-Wilk). The data were analyzed through the GLM procedure of SAS and the means were compared by the Tukey test $(\alpha=0.05)$ for the effect of the genetic groups and genotypes of each gene.

\section{RESULTS AND DISCUSSION}

In the sheep of this study, the occurrence of the band changes in the exon 6 region of $S C D$ gene which proved monomorphic by the PCR-Single Strain Conformation Polymorphism (SSCP) technique was not verified. The same behavior also occurred in the region of the exon 8 of the $D G A T-1$ gene in the present study (Figure 1). 


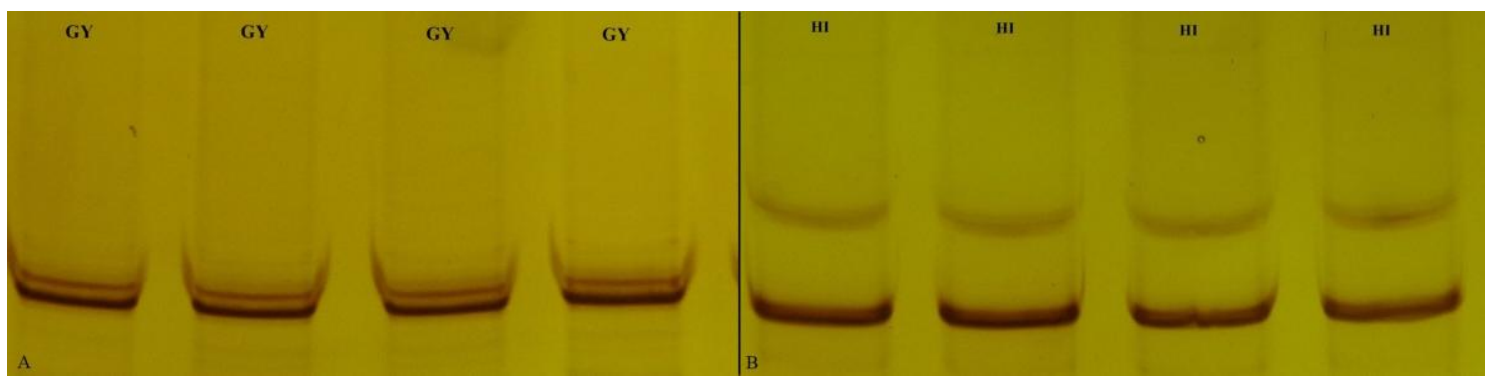

Figure 1. 12.5\% polyacrimalyde gel using the PCR-SSCP technique identifying monomorphic genotypes: (A) GY genotypes in $S C D$ gene and (B) HI genotypes in DGAT-1 gene.

Using PCR-RFLP technique in goats, the results found by Ozmen and Kul (2014) did not demonstrate the occurrence of SNPs in the exon 8 region for that $D G A T-1$ gene. However, seeking to find polymorphisms for DGAT-1 gene and with the use of PCR-RFLP technique in sheep of the Assaf breed, Dervishi et al. (2015) detected a SNP in the exon 1, responsible for the amino acid alteration in position p. Asp53Glu, two SNPs in the exon 17 and a SNP in the intron 10 , which promotes an amino acid alteration in position p. Arg482Cys. Considering the results presented, possible polymorphisms in the exon 8 of those genes, only will be able to be detected with the application of other analytical techniques and/or in other groups of sheep of different genotypes or submitted to different treatments.
Therefore, in relation to the amino acid profile in sheep, it was not possible to infer a relationship of polymorphisms in the studied regions of $S C D$ (exon 6) and DGAT-1 (exon 8) genes and the composition of the fatty acids. According to Sañudo et al. (2000), the sheep meat can present different fatty acid profiles according to the breeds, the animals and the diets, by means of genetic selection and alteration in the feeding of the animals, it is possible to obtain meats with better profile of fatty acids and consequently more wholesome.

In DGAT-2 gene by PCR-SSCP technique, the presence of four genotypes (MO, MP, NP and MQ) with 5 alleles (M, O, P, N, Q) was found (Figure 2).

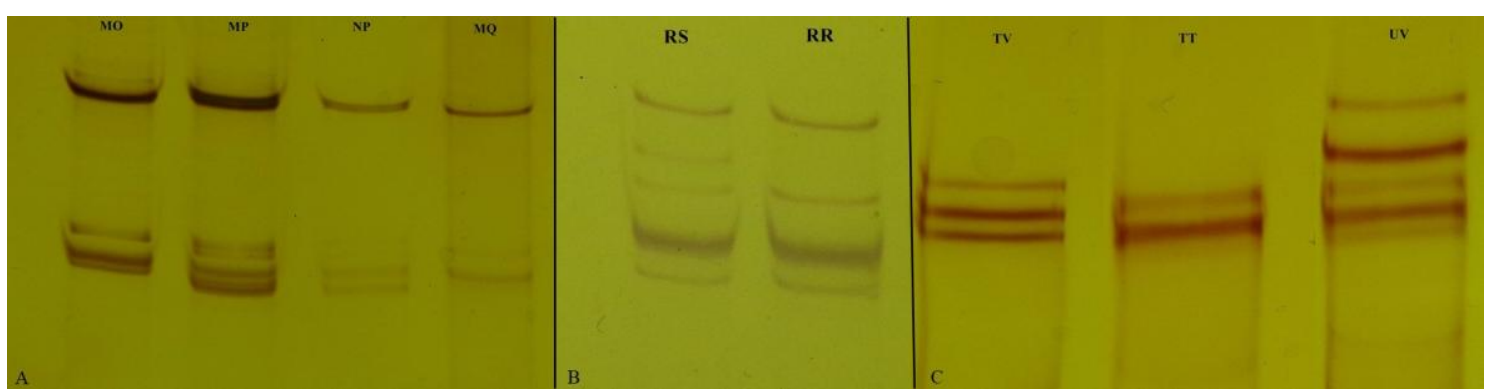

Figure 2. $12.5 \%$ polyacrylamide gel using PCR-SSCP technique identifying the genotypes: (A) four genotypes MO, MP, NP, MQ of SNPs in DGAT-2 gene; (B) two RS and RR genotypes of SNPs on FASN gene; (C) three TV, TT and UV genotypes of SNPs in the TE Thioesterase domain of FASN gene.

The MO genotype in DGAT-2 gene showed higher frequency in the Lacaune x Santa Inês (LC) crossing; while the MP occurred in the East Friesian $\mathrm{x}$ Santa Inês (EF). Animals. The purebred Santa Inês (SI) animals presented higher frequency of the NP genotype, whereas the MQ genotype was found only in the White Dorper x Santa Inês (WD) animals (Table 2). A higher frequency of the M, R and T alleles was observed in DGAT-2, FASN and TE-FASN genes, respectively. Fang et al., (2012) analyzing $D G A T-2$ gene in goats found two alleles (A and $\mathrm{B})$ and two genotypes (AA and $\mathrm{AB}$ ). There was a greater number of individuals with AA genotype than $\mathrm{AB}$, therefore, the $\mathrm{A}$ allele was considered a candidate gene for quantitative traits related to fat absorption, triglyceride synthesis and storage in livestock. 
Table 2. Frequency of the genotypes and polymorphism alleles (SNP) according to the PCR-Single Strand Conformation Polymorphism technique (SSCP) of Diacylglycerol acyltranferase (DGAT-2), Fat Acid Synthase $(F A S N)$ genes and Thioesterase domain of FASN gene (TE-FASN) in each genetic group of sheep

\begin{tabular}{|c|c|c|c|c|c|c|c|c|c|c|}
\hline \multirow{3}{*}{ Gene } & \multirow{3}{*}{ Genotype } & \multicolumn{6}{|c|}{ Genetic Groups* } & \multirow{3}{*}{$\begin{array}{l}\text { Total } \\
\text { FR(\%) }\end{array}$} & \multirow{3}{*}{$\begin{array}{c}\text { Alleles } \\
-\end{array}$} & \multirow{3}{*}{$\begin{array}{c}\text { Frequence } \\
-\end{array}$} \\
\hline & & $\mathrm{LC}$ & SI & $\mathrm{EF}$ & $\mathrm{BD}$ & WD & $\mathrm{TX}$ & & & \\
\hline & & $\mathrm{FR}(\%)$ & $\mathrm{FR}(\%)$ & $\mathrm{FR}(\%)$ & $\mathrm{FR}(\%)$ & $\mathrm{FR}(\%)$ & $\mathrm{FR}(\%)$ & & & \\
\hline \multirow{6}{*}{$\begin{array}{c}\text { DGAT- } \\
2\end{array}$} & $\mathrm{MO}$ & 78.57 & 35.71 & 44.44 & 62.5 & 66.67 & 47.37 & 55.95 & $\mathrm{M}$ & 0.357 \\
\hline & MP & 0.00 & 0.00 & 33.33 & 31.25 & 16.67 & 10.53 & 14.29 & $\mathrm{~N}$ & 0.143 \\
\hline & NP & 21.43 & 64.29 & 22.22 & 6.25 & 8.33 & 42.10 & 28.57 & $\mathrm{O}$ & 0.280 \\
\hline & MQ & 0.00 & 0.00 & 0.00 & 0.00 & 8.33 & 0.00 & 1.19 & $\mathrm{P}$ & 0.214 \\
\hline & - & - & - & - & - & - & - & - & $\mathrm{Q}$ & 0.006 \\
\hline & $\mathrm{RS}$ & 21.43 & 14.29 & 44.44 & 12.5 & 0.00 & 10.53 & 15.48 & $\mathrm{R}$ & 0.923 \\
\hline \multirow[t]{2}{*}{ FASN } & RR & 78.57 & 85.71 & 55.55 & 87.5 & 100.00 & 89.47 & 84.52 & $\mathrm{~S}$ & 0.077 \\
\hline & TV & 71.43 & 92.86 & 88.89 & 100.00 & 83.33 & 73.68 & 84.53 & $\mathrm{~T}$ & 0.493 \\
\hline TE- & TT & 14.29 & 0.00 & 0.00 & 0.00 & 16.67 & 10.53 & 7.14 & $\mathrm{U}$ & 0.042 \\
\hline FASN & UV & 14.29 & 7.14 & 11.11 & 0.00 & 0.00 & 15.79 & 8.33 & $\mathrm{~V}$ & 0.465 \\
\hline
\end{tabular}

*LC - Lacaune x Santa Inês; SI - Purebred Santa Inês; EF - East Friesian x Santa Inês; BD - Black Dorper x Santa Inês; WD - White Dorper x Santa Inês; TX - Texel x Santa Inês; FR = Relative frequence $(\%)$.

The data obtained in the sequencing of each genotype of the region of the exon $8 D G A T-2$ gene revealed the presence of six polymorphisms, which represent base change (A/G, C/G and A/T) and base deletion (Figure 3).

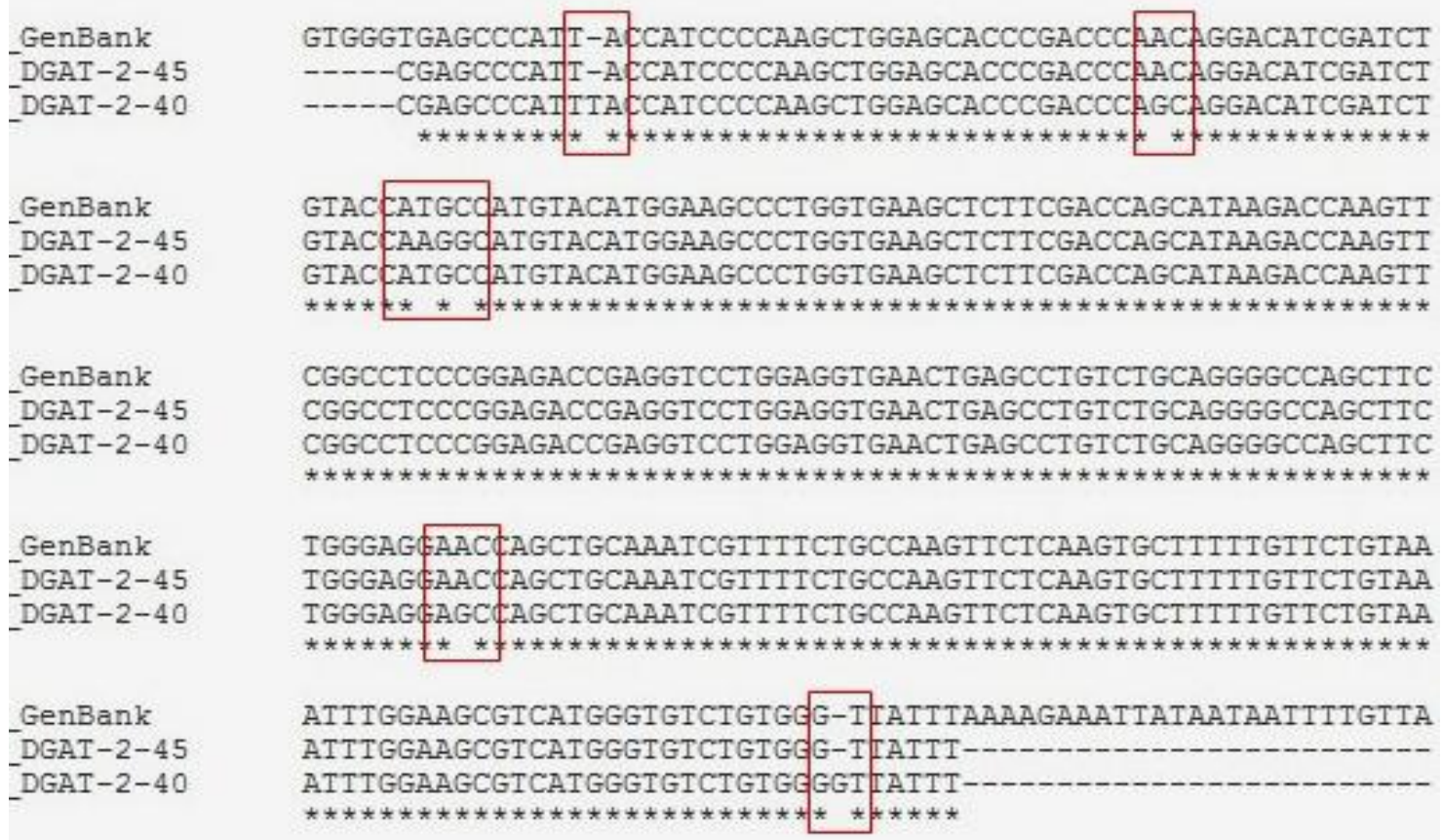

Figure 3. Partial alignment using tools from the JustBio site (2016) of two samples of DGAT-2 gene and of the DGAT-2 gene sequence deposited in GenBank, accession number XM_012154874.1. The similarities are indicated by an asterisk $\left.{ }^{*}\right)$ and the differences by the absence of the same. 
In two SNPs of DGAT-2 gene, the polymorphisms (c.229T>C; c. $255 \mathrm{~T}>\mathrm{C})$, resulted into the change of phenylalanine for leucine (Figure 4).

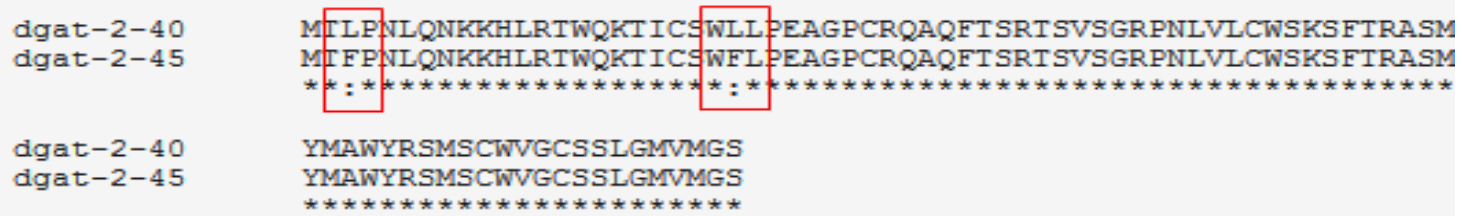

Figure 4. Partial alignment using tools from the Clustal omega site, from three different protein samples of $D G A T-2$ gene. The similarities are indicated by an asterisk (*) and the differences by the absence of the same.

Fang et al. (2012) also reported the presence of SNPs for DGAT-2 gene, with the presence of 7 polymorphisms in the exon 3 in the study with different goat breeds, using PCR-SSCP technique, one of which is characterized by the base change $A / G$ ) which resulted in the exchange of lysine by arginine, however, for the region of the exon 8 of this gene, the authors did not find the presence of SNPs.

In the present study, among the genetic groups evaluated, it was possible to observe two genotypes (RS and RR) and two alleles (R and S) in the exon 6 region of the FASN gene. The frequencies of the genotypes observed were of $15.48 \%$ and $84.52 \%$, respectively, for the RS and RR genotypes (Table 2). Among the crosses, it is found that the EF animals presented higher frequency for the RS genotype; while for the RR genotype, its greatest expression occurred in the Texel x Santa Inês (TX) group. The allele frequencies observed for the FASN gene were of 0.923 and 0.077 for $\mathrm{R}$ and $\mathrm{S}$, respectively.

According to Chu et al. (2015), fatty acid synthase enzyme $(F A S N)$ presents multiple functions related to fatty acid biosynthesis, its gene being an important candidate as a molecular marker, since its expression can interfere with the lipid deposition and consequently in the meat quality of the animals.

In Polish Holstein-Friesian cattle, FASN gene was analyzed by RFLP technique, and three AA, AG and GG genotypes were identified. The AA individuals were characterized by higher milk yield and protein yields (Ciecierska et al., 2013). In Datong yak cattle, studies showed a significant ratio between the polymorphisms in FASN gene and intramuscular fat content (IMF), confirming that genotyping of this gene may be useful to select animals with higher lipid content in the muscle tissue and thus improve meat flavor (Chu et al., 2015).

After several alignments with sequences deposited in the NCBI database, it was not possible to detect the possible polymorphisms in the sequences generated for FASN gene in this study. The results showed that the size of the amplification fragment (228 bp) was consistent with the target and had a good specificity, which could be directly analyzed by PCR-SSCP technique. In spite of not being possible to make considerations about the occurrence of polymorphism in the present study for the sheep FASN gene in cattle, Dongyep et al. evaluating the presence of SNPs for a total of 10 exons (1, $19,21,23,24,28,34,37,39$ and 42) only found the occurrence of polymorphisms for five sites (exon 23, 24, 34, 37 and 39), demonstrating that distinct behavior may occur in relation to the region of the gene evaluated.

The Thioesterase domain of the FASN gene (TE$F A S N$ ) was analyzed in the region of the exon 6 by the PCR-SSCP technique and revealed three original band patterns (TV, TT and UV) for the animals of this study (Figure 2).

The animals of the cross between Black Dorper and Santa Inês (BD) presented only frequency for the TV genotype; while for the cross between White Dorper and Santa Inês (WD), a higher frequency was observed for the TT genotype and the Texel x Santa Inês (TX) animals presented higher frequency for the UV genotype. Among the genetic groups evaluated, the TV genotype was the one with the highest prevalence in the group of animals studied. The allele frequencies observed for TE-FASN were $0.493,0.042$ and 
0.465 for $\mathrm{T}, \mathrm{U}$ and $\mathrm{V}$ respectively (Table 2 ), $\mathrm{T}$ allele being the most frequent.
The TE-FASN domain genotyping revealed 17 polymorphisms, with two base changes and 15 base deletions (Figure 5).

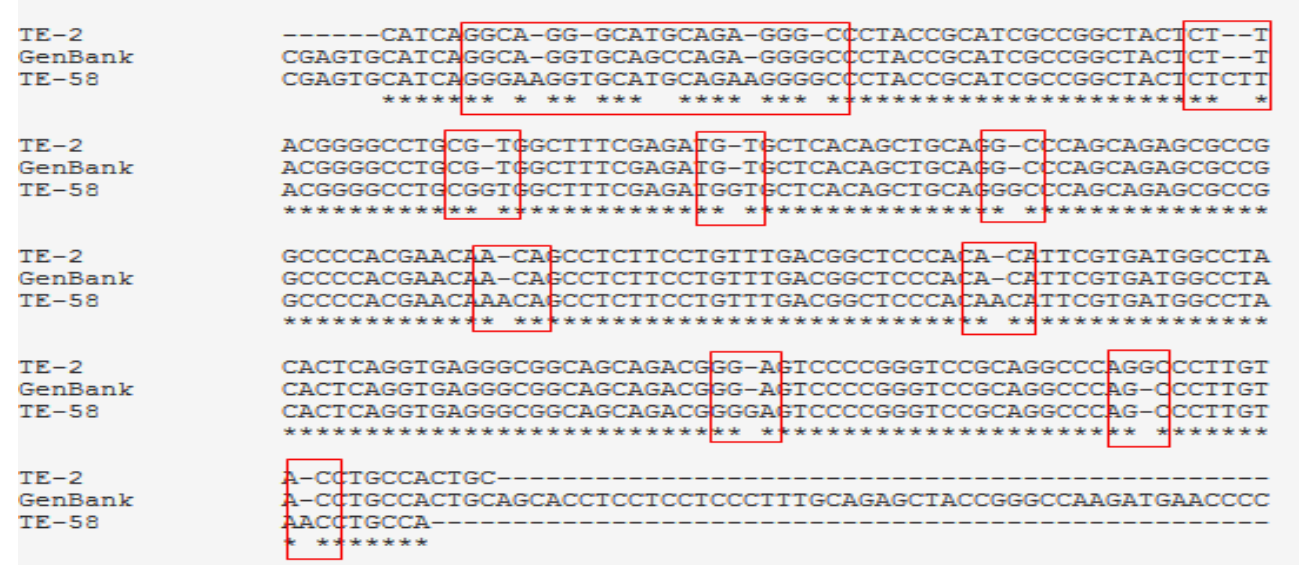

Figure 5. Partial alignment using tools from the JustBio site (2016) of two samples of TE-FASN gene and the TE-FASN gene sequence deposited in GenBank, accession number JN570752.2. The similarities are indicated by an asterisk $(*)$ and the differences by the absence of the same.

One of the first investigations of polymorphisms in $T E-F A S N$ gene was performed in Angus cattle with the use of RFLP technique. The polymorphism found by Zhang et al. (2008) in that region (g.17924A> G) was associated with the composition of fatty acids in the Longissimus dorsi muscle. According to these authors, this mutation would be related to the change in the function of Thioesterase enzyme, so that the release of the fatty acid chain occurs when they reached 18 carbons. Thus, reducing the proportions of $\mathrm{C} 14: 0$ and $\mathrm{C} 16: 0$ in the adipose tissue and generating difference in the composition of fatty acids between the individuals.

For the lipid composition, there was effect of the genetic groups on the values of fatty acids C10:0,

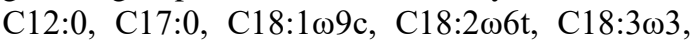
$\mathrm{C} 20: 2$, Total of $\omega 3 / \Omega 6$ and atherogenicity index. Influence was observed in relation to the polymorphism presented in DGAT-2 gene for fatty acids $\mathrm{C} 14: 1, \mathrm{C} 18: 0$ and index of $\triangle 9$ desaturase $^{\mathrm{C} 18}$ and of the genotypes of TE-FASN

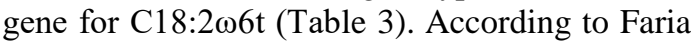
et al. (2005), the lipid profile is related to increased genetic predisposition for fat deposition and these variations may be related to the activity of the Stearoyl-CoA desaturase enzyme $(S C D)$. However, in this study the presence of SNPs for SCD gene was not found, indicating that the effects on the fatty acid profile may also be related to its expression and/or variability in the different species.

The sheep of the LC genetic group presented higher contents of $\mathrm{C} 10: 0$ and C12:0 fatty acids and $\mathrm{C} 17: 0, \mathrm{C} 18: 3 \omega 3$ fatty acids; total $\omega 3$ and $\omega 3 / \omega 6$ ratio were observed in greater quantity in TX sheep (Table 4). Influence of breeds and genetic groups on the lipid profile is found in the literature. Juárez et al. (2009) who described differences in the levels of C12:0, C14:0 and C18:0 fatty acids, with higher values for the Churra Lebrijana breed (mutton breed) than for Grazalema Merino (dairy breed). Landim et al. (2011) studying the profile of fatty acids in sheep, found higher percentage of C17:1 in the muscle of Texel $\times$ Santa Inês in relation to the Santa Inês and Ille de France $x$ Santa Inês animals, considering this difference due to the greater earliness of the Texel breed.

The WD animals revealed higher means of C20:2 and C18:169c (Table 4). That result may be related to the earliness of the WD group. The animals in this study were slaughtered at younger ages, so the lipid profile is represented by the phospholipids of the cell membranes with highest amounts of monounsaturated fatty acids (Wood et al., 2008). As the animals reach maturity, the deposition of lipids in the form of triglycerides tends to increase and provide modification of the fatty acid profile, since the 
amount of phospholipids remains relatively constant. And that can be verified in the study by Madruga et al. (2006) by evaluating the lipid profile of lambs of the Santa Inês and $1 / 2$ Santa Inês x $1 / 2$ Dorper breeds slaughtered late (mean weight of $90 \mathrm{~kg}$ ), where lower proportions of monounsaturated fatty acids and higher proportions of polyunsaturated fatty acids for the animals of the cross with Dorper were found.

Table 3. Means of fatty acids, lipid composition and significance (P value) according to the genetic group and gene polymorphism

\begin{tabular}{|c|c|c|c|c|c|c|}
\hline \multirow{3}{*}{ Fatty acids (AG) } & \multirow{3}{*}{ General Mean } & \multirow{3}{*}{$\begin{array}{c}\text { Standard } \\
\text { Deviation }\end{array}$} & \multicolumn{4}{|c|}{ Value of $\mathrm{P}^{*}$} \\
\hline & & & \multirow{2}{*}{$\begin{array}{l}\text { Genetic } \\
\text { Group }\end{array}$} & \multicolumn{3}{|c|}{ Genes } \\
\hline & & & & DGAT-2 & FASN & TE-FASN \\
\hline C8:0 & 0.003 & 0.006 & 0.354 & 0.753 & 0.690 & 0.228 \\
\hline C10:0 & 0.220 & 0.112 & 0.020 & 0.711 & 0.493 & 0.764 \\
\hline C11:0 & 0.053 & 0.031 & 0.207 & 0.812 & 0.843 & 0.464 \\
\hline C12:0 & 0.093 & 0.027 & 0.039 & 0.248 & 0.976 & 0.468 \\
\hline $\mathrm{C} 13: 0$ & 0.086 & 0.043 & 0.776 & 0.794 & 0.289 & 0.174 \\
\hline $\mathrm{C} 14: 0$ & 2.747 & 0.621 & 0.130 & 0.631 & 0.607 & 0.261 \\
\hline C14:1 & 0.196 & 0.095 & 0.174 & 0.042 & 0.508 & 0.382 \\
\hline $\mathrm{C} 15: 0$ & 1.608 & 0.548 & 0.571 & 0.698 & 0.540 & 0.471 \\
\hline C15:1 & 0.029 & 0.040 & 0.152 & 0.649 & 0.052 & 0.569 \\
\hline C16:0 & 23.274 & 3.076 & 0.066 & 0.555 & 0.399 & 0.874 \\
\hline C16:1 & 3.334 & 0.813 & 0.237 & 0.380 & 0.604 & 0.185 \\
\hline C17:0 & 3.432 & 0.856 & 0.001 & 0.834 & 0.370 & 0.967 \\
\hline $\mathrm{C} 17: 1$ & 3.023 & 1.261 & 0.793 & 0.391 & 0.211 & 0.846 \\
\hline C18:0 & 9.198 & 2,834 & 0.208 & 0.031 & 0.407 & 0.660 \\
\hline $\mathrm{C} 18: 1 \omega 9 \mathrm{t}$ & 6.143 & 3.336 & 0.120 & 0.546 & 0.180 & 0.071 \\
\hline $\mathrm{C} 18: 1 \omega 9 \mathrm{c}$ & 42.738 & 5.707 & 0.049 & 0.486 & 0.224 & 0.597 \\
\hline $\mathrm{C} 18: 2 \omega 6 \mathrm{t}$ & 0.165 & 0.069 & 0.029 & 0.591 & 0.634 & 0.027 \\
\hline $\mathrm{C} 18: 2 \omega 6 \mathrm{c}$ & 3.124 & 0.893 & 0.105 & 0.162 & 0.464 & 0.906 \\
\hline C20:0 & 0.045 & 0.031 & 0.081 & 0.465 & 0.425 & 0.417 \\
\hline $\mathrm{C} 18: 3 \omega 6$ & 0.116 & 0.100 & 0.721 & 0.733 & 0.168 & 0.648 \\
\hline $\mathrm{C} 18: 3 \omega 3$ & 0.184 & 0.094 & 0.014 & 0.168 & 0.730 & 0.597 \\
\hline $\mathrm{C} 21: 0$ & 0.046 & 0.056 & 0.907 & 0.922 & 0.163 & 0.792 \\
\hline C20:2 & 0.020 & 0.021 & 0.028 & 0.716 & 0.508 & 0.382 \\
\hline $\mathrm{C} 20: 3 \omega 6$ & 0.017 & 0.011 & 0.064 & 0.394 & 0.402 & 0.359 \\
\hline $\mathrm{C} 20: 4 \omega 6$ & 0.102 & 0.040 & 0.354 & 0.505 & 0.512 & 0.336 \\
\hline \multicolumn{7}{|l|}{ Summation } \\
\hline$\sum$ Saturated (SAT) & 40.876 & 4.627 & 0.094 & 0.550 & 0.387 & 0.877 \\
\hline $\begin{array}{c}\sum \text { Monounsaturated } \\
(\mathrm{MON})\end{array}$ & 55.463 & 4.857 & 0.098 & 0.474 & 0.334 & 0.915 \\
\hline$\underset{(\mathrm{POL})}{\sum \text { Polyunsaturated }}$ & 3.731 & 0.989 & 0.098 & 0.193 & 0.580 & 0.855 \\
\hline$\sum \omega 3$ & 0.184 & 0.094 & 0.014 & 0.117 & 0.730 & 0.597 \\
\hline$\sum \omega 6$ & 3.525 & 0.921 & 0.110 & 0.206 & 0.536 & 0.810 \\
\hline$\Sigma \mathrm{POL} / \Sigma \mathrm{SAT}$ & 0.092 & 0.027 & 0.098 & 0.291 & 0.800 & 0.789 \\
\hline \multicolumn{7}{|l|}{ Ratio } \\
\hline$\Sigma \omega 6 / \Sigma \omega 3$ & 24.054 & 15.139 & 0.104 & 0.302 & 0.158 & 0.383 \\
\hline$\Sigma \omega 3 / \Sigma \omega 6$ & 0.051 & 0.018 & 0.017 & 0.223 & 0.219 & 0.085 \\
\hline \multicolumn{7}{|l|}{ Index } \\
\hline$\Delta 9$-desaturase ${ }^{\mathrm{C} 16}$ & 12.705 & 3.488 & 0.289 & 0.608 & 0.345 & 0.401 \\
\hline$\Delta 9$-desaturase $\mathrm{C}^{\mathrm{C} 18}$ & 84.203 & 4.534 & 0.155 & 0.048 & 0.400 & 0.805 \\
\hline Elongase $^{\mathrm{C} 16-\mathrm{C} 18}$ & 68.578 & 3.436 & 0.094 & 0.345 & 0.574 & 0.455 \\
\hline Thioesterase $\mathrm{C}^{\mathrm{C} 16-14}$ & 89.525 & 1.305 & 0.625 & 0.924 & 0.810 & 0.079 \\
\hline Atherogenicity & 0.767 & 0.076 & 0.004 & 0.066 & 0.831 & 0.452 \\
\hline Thrombogenicity & 1.188 & 0.249 & 0.176 & 0.566 & 0.335 & 0.890 \\
\hline
\end{tabular}


The polymorphisms...

Table 4. Means of the lipid composition of sheep by reason of the genetic groups

\begin{tabular}{|c|c|c|c|c|c|c|c|c|c|}
\hline \multirow{2}{*}{ Variables } & \multicolumn{6}{|c|}{ Genetic Group } & \multirow{2}{*}{ Average } & \multirow{2}{*}{ EPM } & \multirow{2}{*}{ Value of $\mathrm{P} * *$} \\
\hline & $\mathrm{BD}$ & $\mathrm{EF}$ & LC & SI & $\mathrm{TX}$ & WD & & & \\
\hline C10:0 & $0.245 \mathrm{ab}$ & $0.187 \mathrm{ab}$ & $0.304 a$ & $0.161 b$ & $0.206 \mathrm{ab}$ & $0.208 \mathrm{ab}$ & 0.220 & 0.036 & 0.020 \\
\hline C12:0 & $0.103 \mathrm{ab}$ & $0.081 \mathrm{ab}$ & $0.110 \mathrm{a}$ & $0.081 b$ & $0.090 \mathrm{ab}$ & $0.092 \mathrm{ab}$ & 0.093 & 0.009 & 0.039 \\
\hline $\mathrm{C} 17: 0$ & $3.705 \mathrm{ab}$ & $3.143 b$ & $3.098 \mathrm{~b}$ & $3.21 \mathrm{~b}$ & $4.141 \mathrm{a}$ & $3.14 \mathrm{~b}$ & 3.432 & 0.237 & 0.001 \\
\hline $\mathrm{C} 18: 1 \omega 9 \mathrm{c}$ & $41.215 \mathrm{ab}$ & $42.171 \mathrm{ab}$ & $42.019 \mathrm{ab}$ & $46.172 \mathrm{ab}$ & $40.565 b$ & $45.121 \mathrm{a}$ & 42.738 & 1.802 & 0.049 \\
\hline $\mathrm{C} 18: 2 \omega 6 \mathrm{t}$ & $0.176 \mathrm{ab}$ & $0.158 \mathrm{ab}$ & $0.143 \mathrm{ab}$ & $0.206 a$ & $0.126 \mathrm{~b}$ & $0.182 \mathrm{ab}$ & & 0.022 & 0.029 \\
\hline $\mathrm{C} 18: 3 \omega 3$ & $0.188 \mathrm{ab}$ & $222 a b$ & $0.161 \mathrm{ab}$ & $0.170 \mathrm{ab}$ & $0.245 \mathrm{a}$ & $0.123 b$ & & 0.029 & 4 \\
\hline $\mathrm{C} 20: 2$ & $0.020 \mathrm{ab}$ & $0.019 \mathrm{ab}$ & $0.009 b$ & $0.021 \mathrm{ab}$ & $0.018 \mathrm{ab}$ & $0.038 \mathrm{a}$ & & 0.007 & 0.028 \\
\hline$\sum \omega 3$ & $0.188 \mathrm{ab}$ & $0.222 \mathrm{ab}$ & $0.161 \mathrm{ab}$ & $0.170 \mathrm{ab}$ & $0.245 \mathrm{a}$ & $0.124 b$ & & 0.029 & 0.014 \\
\hline$\sum \omega 3 / \sum \omega 6$ & $0.055 \mathrm{ab}$ & $0.056 \mathrm{ab}$ & $0.046 \mathrm{ab}$ & $0.046 \mathrm{ab}$ & $0.063 \mathrm{a}$ & $0.040 \mathrm{~b}$ & 0.051 & 0.006 & 0.017 \\
\hline Atherogenicity & $0.756 \mathrm{ab}$ & $0.759 \mathrm{ab}$ & $0.822 \mathrm{a}$ & $0.758 \mathrm{ab}$ & $0.717 \mathrm{~b}$ & $0.798 \mathrm{a}$ & 0.767 & 0.023 & 0.004 \\
\hline
\end{tabular}

*LC - Lacaune x Santa Inês; SI - Santa Inês puro; EF - East Friesian x Santa Inês; BD - Black Dorper x Santa Inês; WD - White Dorper x Santa Inês; TX - Texel x Santa Inês; SEM =standard error of the mean; ** Tukey's test $(\alpha=0.05)$.

The SI animals presented higher contents of

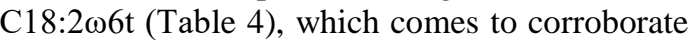
with the results found by Cruz et al. (2011) with Santa Inês sheep, in which they report a higher concentration of this fatty acid.

The highest atherogenicity indices were found for LC and WD animals and the lowest ones for TX sheep (Table 4). These results are related to the ones which present a higher amount of $\mathrm{C} 12: 0$ found in the LC genetic group, which is a fatty acid with an atherogenic potential as well as C14:0 and C16:0 (Menezes Junior et al., 2014), and lower percentages of the $\mathrm{C} 18: 3 \omega 3$ group for the WD group, which is a fatty acid of the $\omega 3$ series and is related to the metabolic synthesis that will produce the prostaglandins that own antithrombogenic and antiatherogenic effect (Perini et al., 2010). While for the TX genetic group, the result was a higher percentage of C18:3 03 that showed almost 2 times the amount found for the LC and WD groups.

For DGAT-2 gene, the MO genotype revealed higher means for $\mathrm{C} 14: 1$ fatty acids and $\Delta 9$ desaturase $^{\mathrm{C} 18}$ index; for stearic acid (C18:0), an inverse behavior occurred with higher average values for NP and lower for MP, showing influence on the composition of these fatty acids in sheep (Table 5). In pigs, Yin et al. (2012) found a variation $(\mathrm{A} / \mathrm{G})$ by the PCR-RFLP method in the 3 'UTR region of DGAT-2 gene and this was related to the modification of the back-fat thickness between the sixth and seventh ribs. Thus, the occurrence of SNPs in the different regions of this gene can promote alteration in lipid composition and deposition.

For the gene of the TE-FANS region, higher average values of $\mathrm{C} 18: 2 \omega 6 \mathrm{t}$ were found for the TV genotype, these being similar to TT and superior to UV.

In this study, the influence of the genetic group and the genotype of the TE-FASN gene were found in relation to the values of $C 18: 2 \omega 6 \mathrm{t}$ (Table 2, 3). Where the genetic groups (TX and LC) that presented higher frequencies of the TT and UV genotype tended to present, although statistically similar, lower values of this fatty acid.

Table 5. Means of the lipid composition of sheep because of the polymorphism of DGAT-2 and TE genes.

\begin{tabular}{cccccccc}
\hline \multirow{2}{*}{ Variables } & \multicolumn{9}{c}{ Genotypes of DGAT-2 gene } & \multirow{2}{*}{ EPM } & \multirow{2}{*}{ Value of P* } \\
\cline { 2 - 5 } & MO & MP & NP & MQ & & 0.042 \\
C14:1 & $0.215 \mathrm{a}$ & $0.212 \mathrm{ab}$ & $0.153 \mathrm{~b}$ & $0.140 \mathrm{c}$ & 0.028 & 0.031 \\
C18:0 & $8.470 \mathrm{~d}$ & $9.441 \mathrm{bc}$ & $10.428 \mathrm{~b}$ & $11.478 \mathrm{a}$ & 0.822 & 0.048 \\
\hline y-desaturase $^{\mathrm{C} 18}$ & $85.317 \mathrm{a}$ & $83.671 \mathrm{ab}$ & $82.390 \mathrm{~b}$ & $80.325 \mathrm{c}$ & 1.327 & 0.027 \\
\hline
\end{tabular}

* Tukey test $(\alpha=0.05) ;$ SEM $=$ standard error of the mean. 
Studies on cattle of the Korean Hanwoo breed, in $F A S N$ gene in the exon 39 in the $T E$ domain region, g.17924 polymorphism $(A>G)$ in the $G G$ genotype was identified and this was associated with higher concentrations of $\mathrm{C} 18: 1 \omega 9$ and lower of C16:0 (Bhuiyan et al., 2009). This same polymorphism was also associated by Maharani et al. (2012) to low levels of myristic fatty acid (C14:0). This demonstrates the importance of conducting further studies on this region of this gene.

\section{CONCLUSION}

The results indicate that PCR-SSCP is an efficient technique to detect polymorphisms in the genes involved in lipid metabolism. Different SNPs were found in DGAT-2 and in TE domain of FASN gene, which could influence the synthesis of certain fatty acids and alter the lipid profile of the meat.

\section{ACKNOWLEDGEMENTS}

The authors thank FAPEMIG (Foundation for Research Support of the State of Minas Gerais) that made possible the realization of this study through the furnishing of financial support.

\section{REFERENCE}

BARTON, L.; KOTT, T.; BURES, D. et al. The polymorphisms of stearoyl-CoA desaturase (SCD1) and sterol regulatory element binding protein-1 (SREBP-1) genes and their association with the fatty acid profile of muscle and subcutaneous fat in Fleckvieh bulls. Meat Sci., v.85, p.15-20, 2010.

BHUIYAN, M.S.A.; YU, S.L.; JEON, J.T. et al. DNA polymorphisms in SREBF1 and FASN genes affect fatty acid composition in Korean cattle (Hanwoo). Asian Aust. J. Anim. Sci., v.22, p.765-773, 2009.

BOUWMAN, A.C.; VISKER, M.H.P.W.; ARENDONK, J.A.M. et al. Genomic regions associated with bovine milk fatty acids in both summer and winter milk samples. BMC Genet., v.13, n.93, 2012.

BYUN, S.O.; FANG, Q.; ZHOU, H. et al. An effective method for silver-staining DNA in large numbers of polyacrylamide gels. Anal. Biochem., v.385, p.174-175, 2009.

CASES, S.; SMITH, S.J.; ZHENG, Y.W. et al. Identification of a gene encoding an acyl CoA: diacylglycerol acyltransferase, a key enzyme in triacylglycerol synthesis. Proc. Natl. Acad. Sci. USA, v.95, p.13018-13023, 1998.
CHU, M.; WU, X.Y.; GUO, X. et al. Association between single-nucleotide polymorphisms of fatty acid synthase gene and meat quality traits in Datong Yak (Bos grunniens). Genet. Mol. Res., v.14, p.2617-2625, 2015.

CIECIERSKA, A.F.; GRZESIAK, W.; PROSKURA, W.S. et al. The influence of fatty acid synthase polymorphism on milk production in polish Holsteinfriesian cattle. J. Anim. Plant Sci., v.23, p.376-379, 2013.

CONTE, G.; MELE, M.; CHESSA, S. et al. Diacylglycerol acyltransferase 1, stearoyl -CoA desaturase 1 , and sterol regulatory element binding protein 1 gene polymorphisms and milk fatty acid composition in Italian Brown cattle. J. Dairy Sci., v.93, p.753-763, 2010.

CRUZ, C.A.C.; SANTOS-CRUZ, C.L.; CASTILLO, C.J.C. et al. Lipidic characterization of Santa Inês lamb shoulder. Cienc. Tecnol. Alimen., v.31, p.508516,2011

DERVISHI, E.; SERRANO, M.; JOYC, M. Structural characterisation of the acyl CoA: diacylglycerol acyltransferase 1 (DGAT1) gene and association studies with milk traits in Assaf sheep breed. Small Ruminant Res., v.131, p.78-84, 2015.

DONGYEP, O.; LEE, Y.; LA, B. et al. Fatty acid composition of beef is associated with exonic nucleotide variants of the gene encoding FASN. Mol. Biol. Rep., v.39, p.4083-4090, 2012.

ERKKILÄ, A.; MELLO, V.D.F.; RISÉRIUS, U. et al. Dietary fatty acids and cardiovascular disease: an epidemiological approach. Prog. Lipid Res., v.47, p.172-187, 2008.

FANG, X.; ZHANG, J.; XU, H. et al. Polymorphisms of diacylglycerol acyltransferase 2 gene and their relationship with growth traits in goats. Mol. Bio. Rep., v.39, p.1801-1807, 2012.

FARIA, P.B.; BRESSAN, M.C.; VIEIRA, J.O. Meat quality and lipid profiles in crossbred lambs finished on clover-rich pastures. Meat Sci., v.90, p.733-738, 2012.

FOLCH, J.; LEES, M.; STANLEY, S.A. A simple method for isolation and purification of total lipids from animal tissues. J. Biol. Chem., v.226, p.479-503, 1957.

GUILLOU, H.; ZADRAVEC, D.; MARTIN, P.G.P. et $a l$. The key roles of elongases and desaturases in mammalian fatty acid metabolism: Insights from transgenic mice. Prog. Lipid Res., v.49, p.186-199, 2010.

HARTMAN, L.; LAGO, R.C.A. Rapid preparation to fatty acids methyl esters. Lab. Pract., v.22, p.475-476, 1973. 
HENRIQUEZ-RODRIGUEZ, E.; TOR, M.; PENA, R.N. et al. A polymorphism in the stearoyl-CoA desaturase gene promoter increases monounsaturated fatty acid content in dry-cured ham. Meat Sci., v.106, p.38-43, 2015.

JUÁREZ, M.; HORCADA, A.; ALCALDE, M.J. et al. Meat and fat qualiy of unweaned lambs as affected by slaughter weight and breed. Meat Sci., v.83, p.308313, 2009.

KAZALA, E.C.; LOZEMAN, F.J.; MIR, P.S. et al. Relationship of fatty acid composition to intramuscular fat content in beef from crossbred wagyu cattle. J. Anim. Sci., v.77, p.1717-1725, 1999.

\section{LANDIM, A.V.; CARDOSO, M.T.M.;} CASTANHEIRA, M.C. et al. Fatty acid profile of hair lambs and their crossbreds slaughtered at different weights. Trop. Anim. Health Prod., v.43, p.1561-1566, 2011.

MADRUGA, M.S.; ARAUJO, W.O.; SOUSA, W.H. et al. Efeito do genótipo e do sexo sobre a composição química e do perfil de ácidos graxos da carne de cordeiros. Rev. Bras. Zootec., v.35, p.1838-1844, 2006.

MAHARANI, D.; JUNG, Y.; JUNG, W.Y. et al. Association of five candidate genes with fatty acid composition in Korean cattle. Mol. Biol. Rep., v.39, p.6113-6121, 2012.

MALAU-ADULI, A.E.O; SIEBERT, B.D.; BOTTEMA, C.D.K. et al. A comparison of the fatty acid composition of triacylglycerols in adipose tissue from Limousin and Jersey cattle. Aust. J. Agric. Res., v.48, p.715-722, 1997.

MCFIE, P.J.; BANMAN, S.L.; KARY, S. et al. Murine diacylglycerol acyltransferase-2 (DGAT2) can catalyze triacylglycerol synthesis and promote lipid droplet formation independent of its localization to the endoplasmic reticulum. J. Biol. Chem., v.286, p.28235-28246, 2011.

MENEZES JUNIOR, E.L.; BATISTA, A.S.M.; LANDIM, A.V. et al. Qualidade da carne de ovinos de diferentes raças de reprodutores terminados sob dois sistemas de produção. Rev. Bras. Saúde Anim., v.15, p.517-527, 2014.

OZMEN, O.; KUL, S. Polymorphism of goat DGAT1 gene and their association with milk production traits. Indian J. Anim. Sci., v.84, p.867-871, 2014.
OZTABAK, K.; GURSEL, F.E.; AKIS, I. et al. FASN gene polymorphism in indigenous cattle breeds of Turkey. Folia Biol. Krakow, v.62, p.29-35, 2014.

PERINI, J.A.L.; STEVANATO, F.B.; SARGI, S.C. et al. Ácidos graxos poli-insaturados n-3 e n-6: metabolismo em mamíferos e resposta immune. Rev. Nutr., v.23, p.1075-1086, 2010.

REGITANO, L.C.A. Extração de DNA para aplicação em reação de cadeia da polimerase. In: REGITANO, L.C.A.; COUTINHO, L.L. (Eds.). Biologia molecular aplicada à produção animal. Brasília: Embrapa, 2001. p.179-186.

SAÑUDO, C.; ENSER, M.E.; CAMPO, M.M. et al. Fatty acid composition and sensory characteristics of lamb carcasses from Britain and Spain. Meat Sci., v.54, p.339-346, 2000.

STATISTICAL analysis system. Version 9.3. Cary: SAS Institute, 2011.

ULBRICHT, T.L.V.; SOUTHGATE, D.A.T. Coronary heart disease:seven dietary factors. Lancet, v.338, p.985-992, 1991.

WOOD, J.D.; ENSER, M.; FISHER, A.V. et al. Fat deposition, fatty acid composition and meat quality: a review. Meat Sci., v.78, p.343-358, 2008.

WOOD, J.G.; RICHARDSON, R.I.; NUTE, G.R. et al. Effects of fatty acids on meat quality: a review. Meat Sci., v.66, p.21-32, 2003.

YIN, Q.; YANG, H.W.; HAN, X.L. et al. Isolation, mapping, SNP detection and association with backfat traits of the porcine CTNNBL1 and DGAT2 genes. Mol. Biol. Rep., v.39, p.4485-4490, 2012.

ZHANG, C.L.; GAO, X.Y.; SHAO, R.Y. et al. Stearoyl-CoA desaturase (SCD) gene polymorphism in goat breeds. Biochem. Genet., v.48, p.822-828, 2010.

ZHANG, S.; KNIGHT, T.J.; REECY, J.M. et al. DNA polymorphisms in bovine fatty acid synthase are associated with beef fatty acid composition. Anim. Genet., v.39, p.62-70, 2008.

ZHANG, Z.; SHU, G.; ZHU, X. et al. Effect of diacylglycerol acyltransferase 2 overexpression in 3T3-L1 is associated to an increase in monounsaturated fatty acid accumulation. J. Anim. Sci. Biol., v.5, p.1-8, 2014. 